\title{
Construction and technical modification of grinding wheels for internal cylindrical grinding using SCAMPER method of creative innovation design
}

\author{
Jarosław PLICHTA, Krzysztof NADOLNY, Emilia GIERSZEWSKA
}

DOI: 10.30464/jmee.2018.2.1.27

Online: http://www.jmee.tu.koszalin.pl/download_article/jmee_2018_01_027032.pdf

Cite this article as:

Plichta J., Nadolny K., Gierszewska E. Construction and technical modification of grinding wheels for internal cylindrical grinding using SCAMPER method of creative innovation design. Journal of Mechanical and Energy Engineering, Vol. 2(42), No. 1, 2018, pp. 27-32.

\section{VOLUME 2(42) | No. 1 | APRIL 2018}

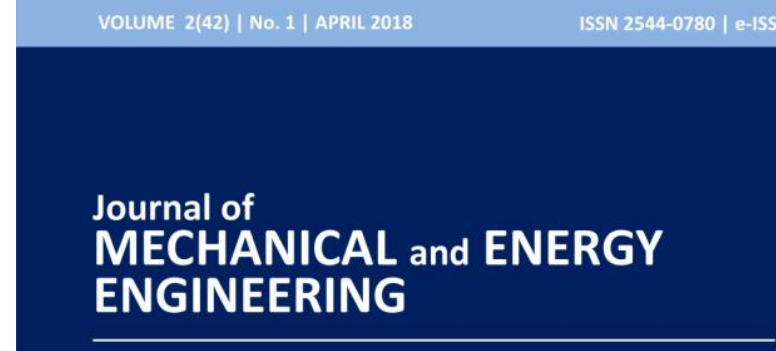

\section{Editor-in-Chief}

Waldemar Kuczyński

Editors

Krzysztof Rokosz | Krzysztof Nadolny
Journal of Mechanical and Energy Engineering

ISSN (Print): 2544-0780

ISSN (Online): 2544-1671

Volume: $2(42)$

Number: 1

Year: 2018

Pages: $27-32$

Article Info:

Received 25 January 2018

Accepted 27 February 2018

Open Access

This article is distributed under the terms of the Creative Commons Attribution 4.0 (CC BY 4.0) International License (http://creativecommons.org/licenses/by/4.0/), which permits unrestricted use, distribution, and reproduction in any medium, provided you give appropriate credit to the original author(s) and the source, provide a link to the Creative Commons license, and indicate if changes were made. 


\title{
CONSTRUCTION AND TECHNICAL MODIFICATION OF GRINDING WHEELS FOR INTERNAL CYLINDRICAL GRINDING USING SCAMPER METHOD OF CREATIVE INNOVATION DESIGN
}

\author{
Jarosław PLICHTA $^{1 *}$, Krzysztof NADOLNY ${ }^{2}$, Emilia GIERSZEWSKA ${ }^{2}$ \\ ${ }^{1 *}$ Faculty of Mechanical Engineering, Department of Production Engineering, Koszalin University \\ of Technology, Raclawicka 15-17, 75-620 Koszalin, Poland, e-mail: jaroslaw.plichta@ @u.koszalin.pl \\ ${ }^{2}$ Faculty of Mechanical Engineering, Department of Production Engineering, \\ Koszalin University of Technology, Poland
}

(Received 25 January 2018, Accepted 27 February 2018)

\begin{abstract}
This article describes a case study of an application of the method of creating innovations called SCAMPER for the development of new abrasive tools designed for machining of hard-to-cut materials. The SCAMPER method is used for innovative transformations of existing products, aimed at a modernization of their design, a construction and an extension of functions. This method was used in the procedure of modifying abrasive tools and it permitted a generation of a set of innovative solutions in this field. The methodology made it also possible to logically organize individual creative activities supported by the previously accumulated theoretical and experimental knowledge.
\end{abstract}

Keywords: SCAMPER method, innovative tool, grinding process, grinding wheel, hard-to-cut material

\section{INTRODUCTION}

The rapid growth of the automotive, aerospace, shipbuilding and medical industries forces the use of new types of materials with advanced physico-chemical properties. These materials are mostly hard-tocut due to their high strength and toughness, high affinity for machining tools, high friction coefficients and tendency to strengthen under the influence of temperature and deformation $[2,4,21,22]$.

In most cases, conventional grinding wheels with standard grains or super hard grains are used to grind these materials [11, 12]. However, the need for various types of modification of such tools is becoming increasingly common in order to extend their service life and to increase the machining potential. The modifications made so far mainly concern increasing the openness of the abrasive tool structure, among others by using special fillers and spherical corundum grains [19]. New types of crystalline ceramic binders have also been developed, which enable the regulation of intensity and rate of the wear and self-sharpening of tools [5-7]. There are also developed grinding wheels with micro- and macrodis-continuities of their active surfaces [9] as well as various impregnating agents preventing chip adhesion and bonding of tool surfaces $[13,16,17]$.

Despite this development, progress in grinding of hard-to-cut is still insufficient. New solutions for highly efficient abrasive tools are being sought through modifications of existing abrasive tools and completely new constructional solutions. In the Department of Production Engineering at the Koszalin University of Technology, research has been conducted for a long time on the constructional development of new abrasive tools for internal cylindrical grinding, creating their prototypes and conducting operational research. Research was also carried out on their monitoring and diagnostics in the grinding process. Inspirations and directions of this development can be systematized based on the transformation model of the existing product, using nine integrated steps based on the SCAMPER method of the creative innovation design [3]. 


\section{THE IDEA OF THE SCAMPER METHOD}

The SCAMPER method is used for innovative transformations of existing products, aimed at a modernization of their design, construction and an extension of functions. This method assumes that every novelty is a modification of something that already exists [3]. Adaptation to specific needs is done on the basis of a list of questions, exploring the possibilities of specific modifications. A basic list of such questions was prepared in the middle of the 20th century by Robert Eberle. These questions are characterized by a specific logic, and in response to them, one obtains a full variance of innovative solutions of the existing product [3]. The first letters of these questions form the name SCAMPER:

- S - substitute,

- C-combine,

- A-adapt,

- M- modify,

- P-put,

- E-eliminate,

- $\mathrm{R}$ - reverse.

This is a basic list. For the purposes of this paper, an extended working list of questions adapted to the technical problem under development has been evaluated (Tab. 1). The presented steps show the directions of modifications made to grinding wheels used in internal cylindrical grinding processes. They were preceded by an extensive functional analysis and confirmed by exploratory tests. The developed set of structural and technical solutions of new tools has been developed for grinding of hard-to-cut materials [18].

\section{MODIFIED INNOVATIVE ABRASIVE TOOLS}

Constructional and technical modifications of small-sized grinding wheels for internal cylindrical grinding have been designed and mostly made in the form of technical prototypes and have been verified in experimental studies $[1,8-10,13-17,20]$. Particular solutions were presented in Table 2 .

Tab. 1. Extended and modified list of question of the SCAMPER method for problem concerning elaboration of abrasive tools for grinding of hard-to-cut materials (GWAS - grinding wheel active surface)

\begin{tabular}{|c|c|c|c|}
\hline No. & Action & Action direction & Effect \\
\hline & $\begin{array}{l}\text { Remove } \\
\text { something } \\
\text { from a known } \\
\text { product }\end{array}$ & $\begin{array}{l}\text { Fragments of the } \\
\text { grinding wheel } \\
\text { have been } \\
\text { removed }\end{array}$ & $\begin{array}{l}\text { Grinding wheel with } \\
\text { internal cooling } \\
\text { channels }\end{array}$ \\
\hline 2. & $\begin{array}{l}\text { Add } \\
\text { something to } \\
\text { a known } \\
\text { product }\end{array}$ & $\begin{array}{l}\text { Second zone of } \\
\text { rough grinding } \\
\text { was added }\end{array}$ & $\begin{array}{l}\text { Double-layered } \\
\text { grinding wheel for } \\
\text { traverse grinding }\end{array}$ \\
\hline 3. & $\begin{array}{l}\text { Solve the } \\
\text { user's problem }\end{array}$ & $\begin{array}{l}\text { Microcontinuity } \\
\text { was formed on the } \\
\text { GWAS }\end{array}$ & $\begin{array}{l}\text { Reduced clogging of } \\
\text { the GWAS with } \\
\text { chips }\end{array}$ \\
\hline 4. & $\begin{array}{l}\text { Make the } \\
\text { product } \\
\text { simpler }\end{array}$ & $\begin{array}{l}\text { Impregnation of } \\
\text { anti-adhesive } \\
\text { substances has } \\
\text { been introduced }\end{array}$ & $\begin{array}{l}\text { Reduction of GWAS } \\
\text { clogging during } \\
\text { machining and } \\
\text { extension of the } \\
\text { service life }\end{array}$ \\
\hline 5. & $\begin{array}{l}\text { Highlight the } \\
\text { difference }\end{array}$ & $\begin{array}{l}\text { Conventional } \\
\text { abrasive grains } \\
\text { have been repla- } \\
\text { ced by super-hard } \\
\text { ones }\end{array}$ & $\begin{array}{l}\text { Grinding wheel with } \\
\text { very good cutting } \\
\text { properties and long } \\
\text { service life }\end{array}$ \\
\hline 6. & $\begin{array}{l}\text { Use the } \\
\text { product in } \\
\text { a different } \\
\text { way }\end{array}$ & $\begin{array}{l}\text { The number of } \\
\text { grinding wheels in } \\
\text { one tool was } \\
\text { multiplied }\end{array}$ & $\begin{array}{l}\text { Multi-tool abrasive } \\
\text { head for grinding } \\
\text { and polishing }\end{array}$ \\
\hline 7. & $\begin{array}{l}\text { Make } \\
\text { a substitute }\end{array}$ & $\begin{array}{l}\text { Replacement of } \\
\text { the bond between } \\
\text { the grains by } \\
\text { a centrifugal force }\end{array}$ & $\begin{array}{l}\text { Grinding wheel with } \\
\text { adjustable flexibility }\end{array}$ \\
\hline 8. & $\begin{array}{l}\text { Be creative, } \\
\text { not passive }\end{array}$ & $\begin{array}{l}\text { Multiplication of } \\
\text { abrasive tool } \\
\text { functions }\end{array}$ & $\begin{array}{l}\text { Grinding wheel } \\
\text { enabling rough and } \\
\text { finish grinding as } \\
\text { well as centrifugal } \\
\text { cooling }\end{array}$ \\
\hline 9. & $\begin{array}{l}\text { Observe the } \\
\text { directions of } \\
\text { development }\end{array}$ & $\begin{array}{l}\text { Centrifugal } \\
\text { burnishing was } \\
\text { added }\end{array}$ & $\begin{array}{l}\text { A hybrid grinding } \\
\text { wheel for grinding } \\
\text { with burnishing }\end{array}$ \\
\hline
\end{tabular}

Tab. 2. Structural and technical modifications of small-size grinding wheels for the internal cylindrical grinding processes $[1,8-10,13-17,20]$

\begin{tabular}{llll}
\hline No. Action & \multicolumn{1}{c}{ Action direction } & \multicolumn{1}{c}{ Effect } & Application \\
\hline $\begin{array}{l}\text { Remove } \\
\text { something from } \\
\text { a known product }\end{array}$ & $\begin{array}{l}\text { Fragments of the } \\
\text { grinding wheel have } \\
\text { been removed }\end{array}$ & $\begin{array}{l}\text { Grinding wheel with } \\
\text { internal cooling } \\
\text { channels }\end{array}$ & $\begin{array}{l}\text { Grinding wheel for grinding hard-to-cut materials, } \\
\text { especially ductile, soft materials requiring intensive } \\
\text { cooling in the machining zone }\end{array}$ \\
\hline $\begin{array}{l}\text { Construction } \\
\text { scheme [20] }\end{array}$ & &
\end{tabular}


Tab. 2. Structural and technical modifications of small-size grinding wheels for the internal cylindrical grinding processes $[1,8-10,13-17,20]$ - continued

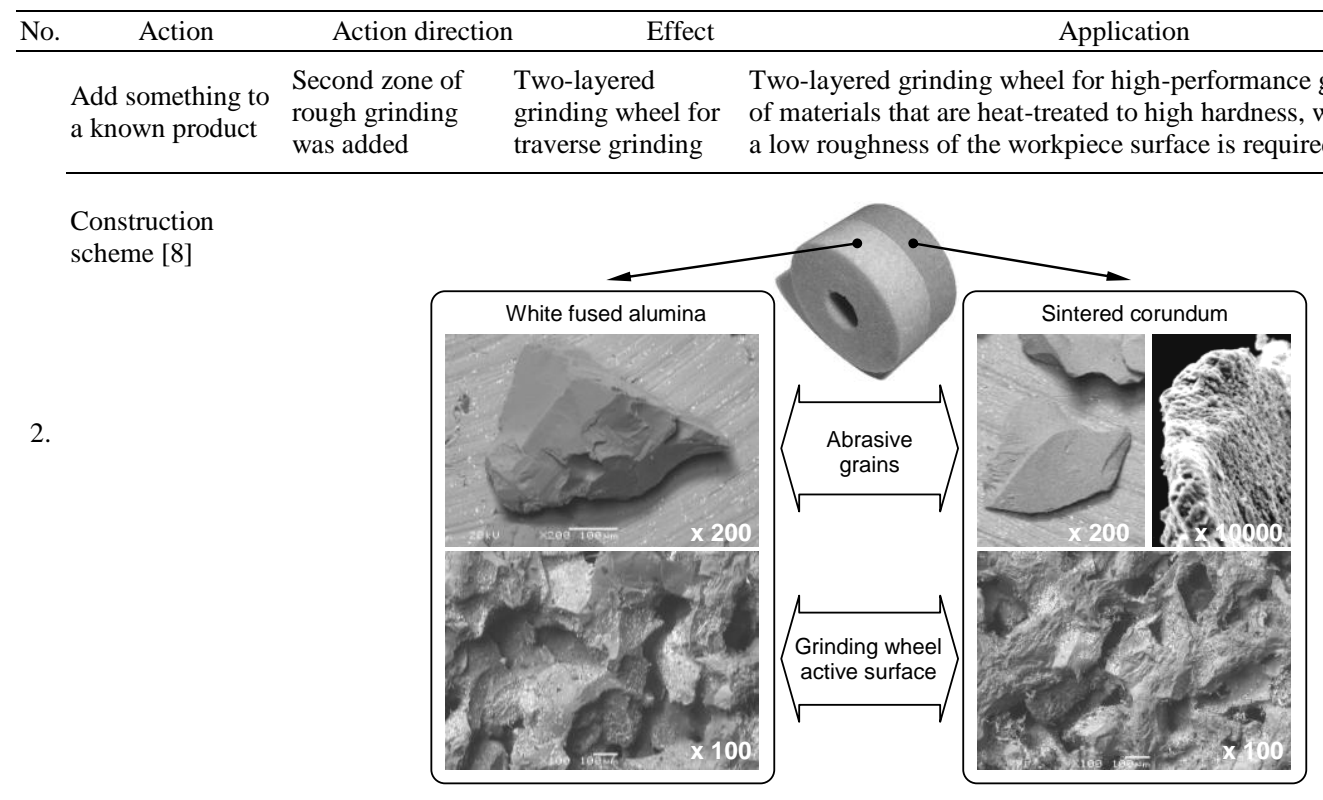

Solve the user's Microcontinuity was Reduced clogging of the problem formed on the GWAS

\section{GWAS with chips}

Grinding wheel for grinding materials that are prone to create surface clogging on the GWAS

Construction

scheme [9]

3.
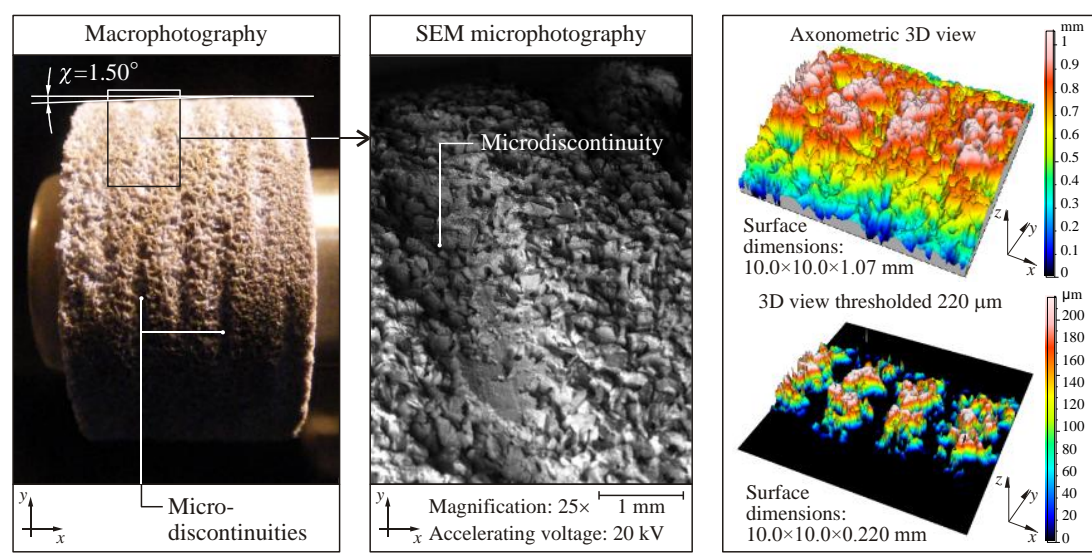

Make the product

Impregnation of anti-

Reduction of GWAS clogging

Grinding wheel for grinding of ductile simpler adhesive substances has during machining surface

Construction

scheme

$[13,16,17]$

4.
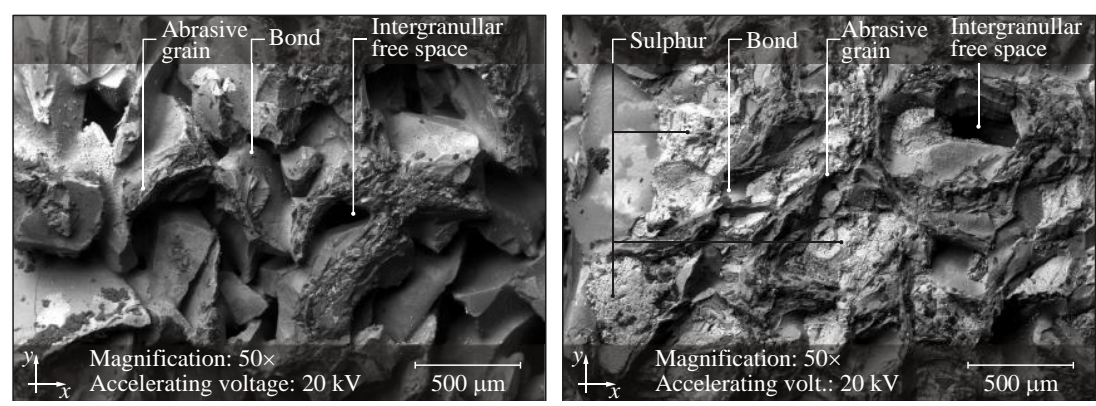
Tab. 2. Structural and technical modifications of small-size grinding wheels for the internal cylindrical grinding processes $[1,8-10,13-17,20]$ - continued

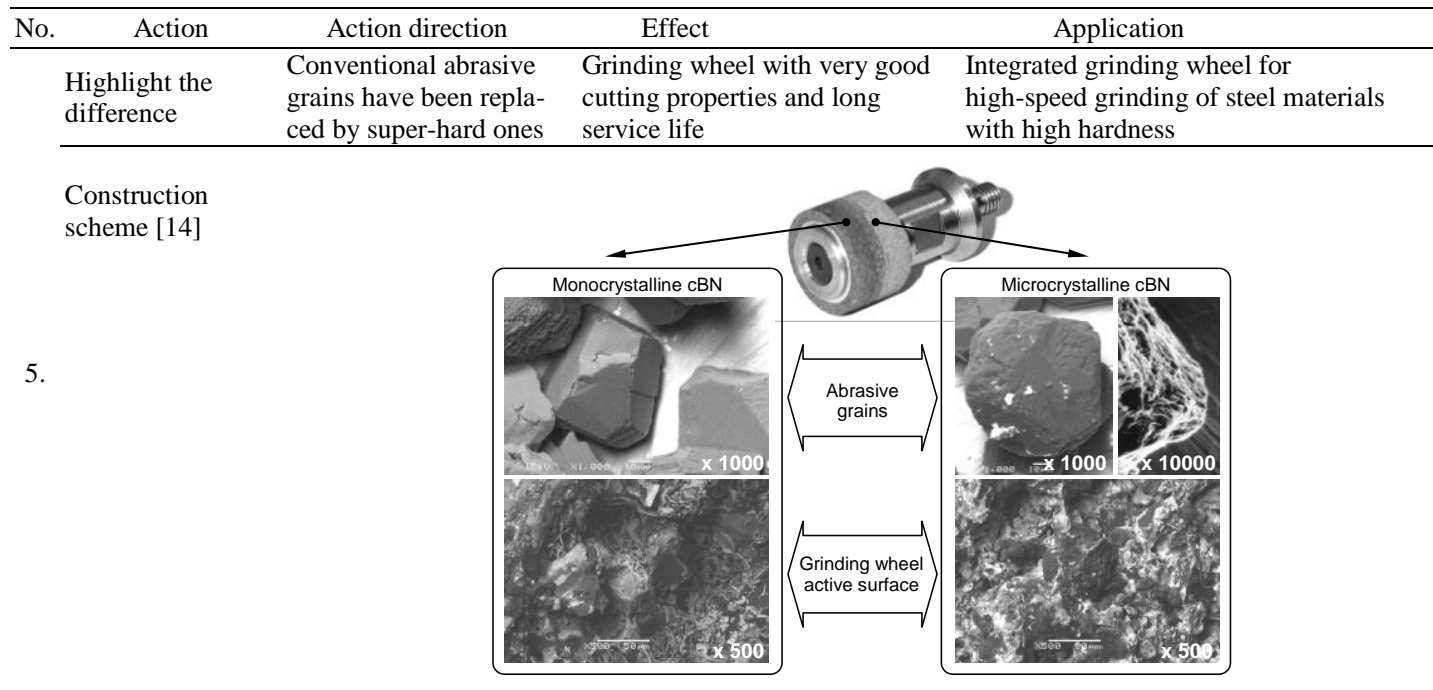

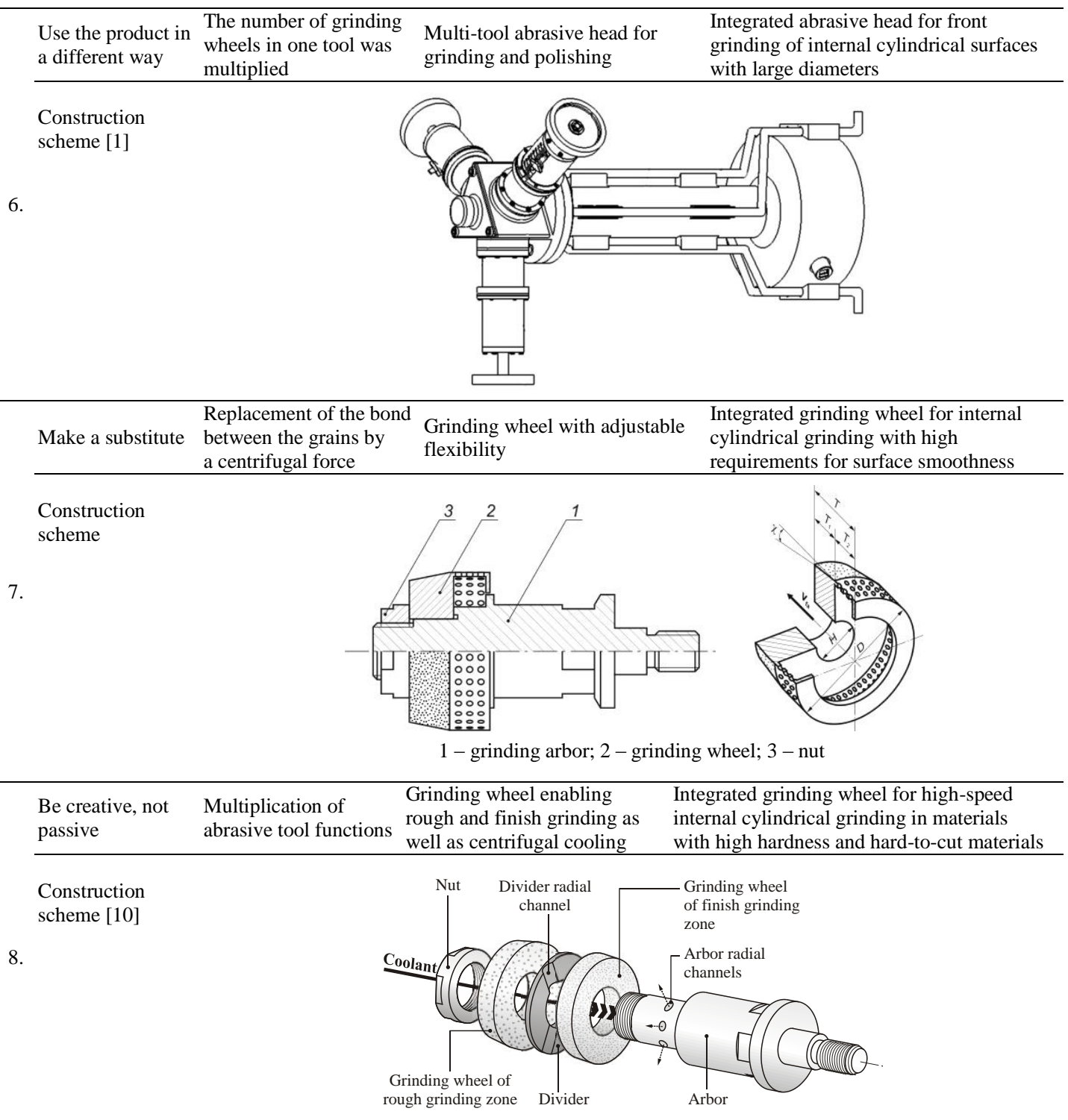


Tab. 2. Structural and technical modifications of small-size grinding wheels for the internal cylindrical grinding processes $[1,8-10,13-17,20]$ - continued

\begin{tabular}{llll}
\hline No. & \multicolumn{1}{c}{ Action } & \multicolumn{2}{c}{ Action direction }
\end{tabular}

\section{FROM IDEA TO PROTOTYPE}

In order to verify the utilitarian design of the modified innovative grinding wheels for internal cylindrical grinding processes described above, prototypes for most of them were made. To this end, certain technical assumptions have been made, based on the results of experimental studies carried out with conventional grinding wheels. The purpose of building these prototypes was to check the technical possibilities of their execution, to collect information on the technological character of particular solutions and to test them in the conditions of selected machining operations. With this in mind, the next steps from concept to prototype in relation to elaborated grinding wheels are shown in Figure 1.

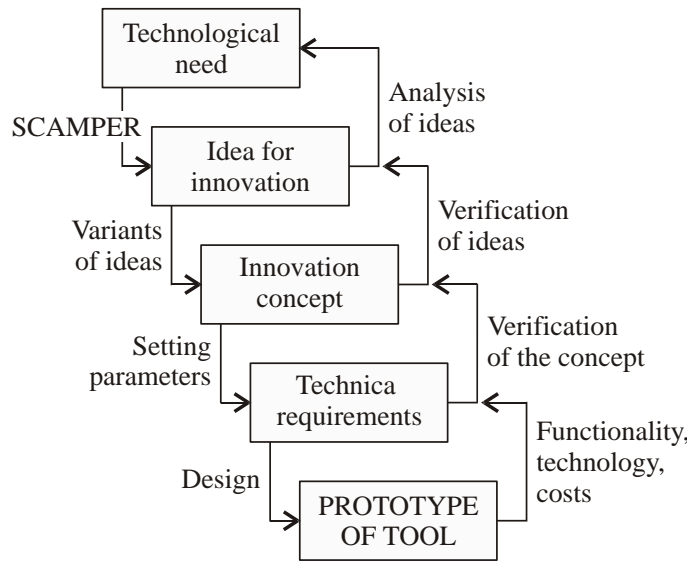

Fig. 1. Sequence of stages of integrated development of design and prototyping of modernized abrasive tools

According to this procedure (Fig. 1), prototypes of abrasive tools were constructed and verified as shown in Table 2. The results of operational tests confirmed their suitability for machining of hard-to-cut materials. The efficiency of machining in relation to conventional tools has increased significantly as well as the operational life of these tools [1, 8-10, 13-17, 20].

\section{CONCLUSIONS}

The SCAMPER method used in the presented procedure of modifying small-sized abrasive tools, on the one hand, allowed to generate innovative solutions and, on the other hand, made it possible to logically organize individual creative activities. These activities were supported by the previously accumulated theoretical and experimental knowledge. However, it should be emphasized that the SCAMPER method made it easier to indicate the directions of search for innovative solutions of construction and technical abrasive tools for internal cylindrical grinding in materials with different technological requirements. The prototypes of selected solutions and tools have met technological expectations and can be the basis for potential development of hole grinding operations.

\section{References}

1. Baran J, Plichta J. (2010) Construction design of a multitool head for grinding of large openings. Mechanic, Vol. 83, No. 2, pp. 135. (in Polish)

2. Bentley S.A., Goh N.P., Aspinwall D.K. (2001) Reciprocating surface grinding of a gamma titanium aluminide intermetallic alloy. Journal of Materials Processing Technology, Vol. 118, pp. 22-28.

3. Cempel C. (2013) Creativity engineering in innovation design. Publishing House of the Institute of Applied Mechanics at Poznań University of Technology, Poznań. (in Polish)

4. Ezugwu E.O. (2005) Key improvements in the machining of difficult-to-cut aerospace superalloys. International Journal of Machine Tools \& Manufacture, Vol. 45, pp. 1353-1367.

5. Herman D. (1998) Glass and glass-ceramic binder obtained from waste material for binding alundum abrasive grains into grinding wheels. Ceramics International, Vol. 24, pp. 515-520.

6. Herman D., Markul J. (2004) Influence of microstructures of binder and abrasive grain on selected operational properties of ceramic grinding wheels made of alumina. International Journal of Machine Tools \& Manufacture, Vol. 44, pp. 511-522.

7. Herman D., Plichta J., Karpinski T. (1997) Effect of glasscrystalline and amorphous binder application to abrasive 
tools made of microcrystalline alumina grains type SG. Wear, Vol. 209, pp. 213-218.

8. Herman D., Plichta J., Nadolny K. (2006) New ceramic abrasive tools for rough and finishing grinding in one pass. Materials Science Forum, Vol. 526, pp. 163-168.

9. Nadolny K. (2013) Microdiscontinuities of the grinding wheel and their effects on its durability during internal cylindrical grinding. Machining Science and Technology, Vol. 17, No. 1, pp. 74-92. DOI: 10.1080/10910344.2012. 747900 .

10. Nadolny K. (2015) Small-dimensional sandwich grinding wheels with a centrifugal coolant provision system for traverse internal cylindrical grinding of steel $100 \mathrm{Cr} 6$ Journal of Cleaner Production, Vol. 93, pp. 354-363. DOI: 10.1016/j.jclepro.2015.01.046

11. Nadolny K., Habrat W. (2017) Potential for improving efficiency of the internal cylindrical grinding process by modification of the grinding wheel structure. Part I: grinding wheels made of conventional abrasive grains. Proceedings of the Institution of Mechanical Engineers, Part E: Journal of Process Mechanical Engineering, Vol. 231, No. 4, pp. 621-632. DOI: 10.1177/ 0954408916637100 .

12. Nadolny K., Habrat W. (2017) Potential for improving efficiency of the internal cylindrical grinding process by modification of the grinding wheel structure. Part II: grinding wheels made of superabrasive grains. Proceedings of the Institution of Mechanical Engineers, Part E: Journal of Process Mechanical Engineering, Vol. 231, No. 4, pp. 813-823. DOI: $10.1177 /$ 0954408916638799.

13. Nadolny K., Kapłonek W., Wojtewicz M., Sienicki W. (2013) Effects of sulfurization of grinding wheels on internal cylindrical grinding of Titanium Grade $2^{\circledR}$. Indian Journal of Engineering \& Materials Sciences, Vol. 20, No. 2, pp. 108-124.

14. Nadolny K., Plichta J. (2005) Single-pass internal cylindrical grinding process with zone-diversified structure grinding wheels. Archives of Mechanical Technology and Materials, Vol. 25, No. 2, pp. 31-40. (in Polish)

15. Nadolny K., Plichta J., Radowski M. (2015) Reciprocal internal cylindrical grinding integrated with centrifugal dynamic burnishing of hard-to-cut materials. Proceedings of the Institution of Mechanical Engineers, Part E: Journal of Process Mechanical Engineering, Vol. 229, No. 4, pp. 265-279. DOI: $10.1177 / 0954408914527925$.

16. Nadolny K., Sienicki W., Wojtewicz M. (2015) The effect upon the grinding wheel active surface condition when impregnating with non-metallic elements during internal cylindrical grinding of titanium. Archives of Civil and Mechanical Engineering, Vol. 15, No. 1, pp. 71-86. DOI: 10.1016/j.acme.2014.03.004.

17. Nadolny K., Sienicki W., Wojtewicz M. (2017) The effect of sulfurization on the grinding wheel cutting ability in the internal cylindrical grinding of nickel superalloys. Proceedings of the Institution of Mechanical Engineers Part B: Journal of Engineering Manufacture, Vol. 231, No. 1, pp. 140-154. DOI: 10.1177/ 0954405415572643.

18. Plichta J., Nadolny K. (2012) Highly effective grinding of hard-to-cut materials. Publishing house of the Koszalin University of Technology, Koszalin. (in Polish)

19. Staniewicz-Brudnik B., Plichta J., Nadolny K. (2005) The effect of porous glass-ceramic materials addition on the cubic boron nitride $(\mathrm{cBN})$ tools properties. Optica Applicata, Vol. 35, No. 4, pp. 810-819.

20. Sutowski P., Nadolny K. (2013) The effect of the method of coolant delivery in the internal cylindrical grinding process on the efficiency of Inconel ${ }^{\circledR}$ alloy 600 machining. Mechanic, Vol. 86, No. 8-9, publication on CD. (in Polish)

21. Teicher U., Ghosh A., Chattopadhyay A.B., Künanz K. (2006) On the grindability of titanium alloy by brazed type monolayered superabrasive grinding wheels. International Journal of Machine Tools \& Manufacture, Vol. 46, pp. 620-622.

22. Tso P.L. (1995) Study on the grinding of Inconel 718. Journal of Materials Processing Technology, Vol. 55, pp. 421-426.

\section{Biographical notes}

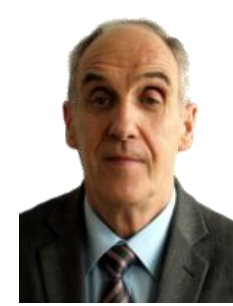

Jaroslaw Plichta received his M.Sc. degree in Mechanics and Machine Design and the next Ph.D as well as D.Sc. degree and the professor title in Machinery Construction and Operation, in 1976, 1981, 1997 and 2010, respectively. Since 2006, he has been the head of the Department of Production Engineering at the Koszalin University of Technology. His scientific interests focus on abrasive processes and tools, monitoring and diagnostics of machining processes as well as metrology. He has been managing 4 national research projects, presenting results of his work at many international and national conferences, published more than 120 scientific papers in international and national journals, book chapters, as well as conference proceedings. He is also the author of 6 monographs, 4 academic textbooks and 11 national patents.

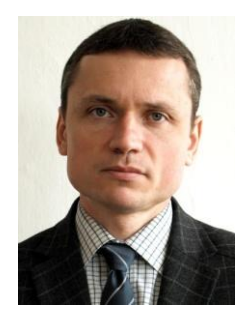

Krzysztof Nadolny received his M.Sc. degree in Mechanics and Machine Design and next the Ph.D (with honors) as well as D.Sc. degree in Machinery Construction and Operation from the Koszalin University of Technology, in 2001, 2006 and 2013, respectively. Since 2006, he has been a researcher in the Department of Production Engineering at the Koszalin University of Technology, where currently he works as an associated professor and the head of the research-didactic team for production planning and control. His scientific interests focus on problems concerning machining processes and tools, efficiency, monitoring and diagnostics of machining processes as well as tribology. He has participated in 2 international and 3 national research projects, presenting results of his work at 10 international and 21 national conferences, published more than 200 scientific papers in international and national journals, book chapters, as well as conference proceedings. He is also the author of 4 monographs and 9 national patents.

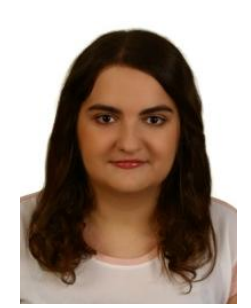

Emilia Gierszewska received her B.Sc. degree in Management and Production Engineering from the Faculty of Mechanical Engineering at the Koszalin University of Technology in 2016. Her scientific interests focus on problems concerning implementation of innovative processes and products, rapid prototyping and reverse engineering methods as well as abrasive machining processes. She has presented the results of her work in one international and two national conferences. She is an author and a co-author of 4 scientific papers in conference proceedings. 